\title{
Reflections on the Development of the College English Teachers in the Age of Curriculum Reform
}

\author{
Qian Li \\ Foreign Languages Department, Shandong Jiaotong University, Jinan, China
}

\begin{abstract}
Since 2002, the Ministry of Education has initiated the college English teaching reform in 180 universities and colleges and it has brought about a series of deep changes which have exerted a profound influence on the learning and teaching habits of the college English students and teachers and urged them to reflect on and pay a close attention to all the factors relevant with the college English teaching. The increasingly developed intelligence of the information technology makes it possible for the technological teaching methods to be widely used in the knowledge-intensive teaching academy. There are many new characteristics of the college English teaching in the information age, such as informationization, individuation and the students' subject status. College English teachers are faced with both challenges and opportunities. The development of the college English teachers should be promoted from the following aspects: reevaluate the activities of college English teaching, to be compound teachers of ESP and EAP through cooperative teaching and school-based training, regard teaching and researching cooperation teams as a creative way to explore college English teaching.
\end{abstract}

Index Terms - reflections, development, college English teachers, curriculum reform

\section{Characteristics of College English Teaching in the New Era}

Yu Mingli. (2005) put forward the concept that the competition among enterprises within the world is ultimately the competition of human resource. Therefore, the training of the talents is of great significance for the whole nation. Nevertheless, the college students who are mainly "after nineties" show quite a lot and great differences from the college students before. These differences are affected by their growing environment and cultivation mode. Therefore, the comprehensive and accurate study of the college students is essential to carry out the college English teaching successfully. Generally speaking, the after-nineties college students show the following characteristics:

\section{A. Informationization}

With the increasingly developed intelligence of the information technology, technological teaching methods have been widely used in the knowledge-intensive teaching academy. The rapid development of technology makes it possible for the replacement of the work by the computers in most areas. On the other hand, the overruns of the university resources drained the potential of universities. Teachers in colleges and universities are busy with teaching activities and scientific research. Meanwhile, they have to conduct intellectual charging and struggle hard under the pressure of work, living and social competition etc. As a result, all of these mentioned above exhausted the physical and mental potential of college teachers and therefore have planted hidden danger for the loss of talent.

Supposed teaching can be developed with the help of the modern information technology and network, it's vital for the improvement of the teaching activities of teachers and learning conditions of the students. The learning modalities of the students can be rich and varied since they have more choices for the time and place of the English study. The learning interest can be greatly aroused and learning result can be extremely enhanced because the monotomous black-board writing has been replaced by vivid three-dimensional knowledge with sound, music, video and pictures which is more attractive. In a word, the use of technological teaching methods is imperatice under such a circumstance.

\section{B. Individuation}

The main body of the college students nowadays are "after nineties" who are the focus of the society. They have distinctive characteristics. On one hand, they are confident and independent. On the other hand, they are sensitive and reliable to some extent. Individualization development of college students is the education mode which high education academy has always attached great importance to. Individualization development has a positive and profound influence on enhancing the college teaching quality and constructing reasonable and effective high education system.

Modern teaching always puts greater emphasis on the collectivized teaching since it was born. Excessive collectivized teaching has limited the development of the individuation. Nowadays, with the development of the modern information technology and social economic status, people have increasingly more chances to reflect on the individuation education and the use of modern information technology with high intelligence makes it possible to 
realize the dream. The students can acquire knowledge with the help of the technological tools independently. Meanwhile, the students can adopt suitable time and place and even learning style which are favorable to them. The learning interest and awareness can be aroused and motivated to the maximum. To meet the demands of individualization development, educational philosophy of student-oriented must be adhered to and carried out.

\section{Students'Subject Status}

Universities and colleges are the places where the students are expected to be cultivated as excellent talents. Most of the students are about 20 years old and are full of energy. On the whole, the college students are of higher quality and bear the responsibilities for the family and the society. Accordingly, the society has placed high expectations on the college students. College students nowadays have an easy access to the internet which enables them to have a quick understanding of what happened worldwide. They accept the western ideas and concepts more easily and have a stronger awareness of their subject status.

Cai Jigang (2007) stated that the adoption of new teaching modes has changed the traditional teaching method which the teachers play a dominative role and the students are passive in the class. The students are given more encouragement and opportunities to take an active part in the teaching activities during the class time. Students are the core of the class and their subject status has excessively increased their learning initiative.

\section{NeCESSities AND SignifiCANCES OF COLlEgE ENGLISH TEACHERS’DEVElOPMENT}

\section{A. Necessities of College English Teachers' Development}

Rui Yanping (2011) stated that the quality of teachers is the critical factor to enhance the quality of teaching and the improve the college English curriculum reform. It cannot be denied that the students' achievements of English learning depend largely on the comprehensible language input and guidance the English teachers can provide in the classroom. Therefore, how the teachers teach and what contents they deliver to the students have a significant influcence on the students' learning. Closely related to it is the overall quality an English teacher has, since a teacher is the single most powerful change agent in raising students' achievements. According to Villegas-Reimers (2003), it is teacher professional development that is one of the key elements in educational reform in the world today. Also, the education and professional development of teachers is regarded as the keystone to educational improvement. As can be seen from the above ideas, to what extent the college English can achieve success depends largely on the professional development of the teachers.

\section{B. Significances of College English Teachers'Development}

Nowadays, the college English teaching lays great emphasis on the practicability which emphasizes that the contents and teaching activities should be real and practical. Besides, the college English teaching pay special attention to the characteristics of times. An increasing number of universities and colleges set up courses such as language skills, language cultures and language applications. The teachers are encouraged to use advanced technologies to provide the students with abundant learning resources and favorable learning environment through teaching based on web-enhanced language learning. Also, many new concepts and things spring up everyday and the knowledge and information are updating anytime. Therefore, it is high time the teachers and students studied hard to keep up with the flow of the ever-changing society and perfect themselves.

It is worth reflecting on the teachers' development when reviewing the history of college English teaching. The biggest barrier to the college English teachers' development is the update of their concepts and professional development. In recent years, a lot of statements are put forward in both the domestic and foreign college English teaching field. Such statements are as the following: "expert teachers", "reflective teachers", "scholar teachers" etc. and these kinds of statements imply that there is a infinite room for the teachers to develop. The teacher possess not only basic knowledge and professional knowledge but also the capicity of teaching, educating and conducting researchs. But the reality is it difficult to achieve the aims mentioned above for the teachers who are burdened with heavy teaching tasks.

In the proceeding years, with the development of the college English teaching reform, it is urgent for the teachers to obtain training to help them be well developed professionally. But it is not realistic for the teachers to have a large scale professional training. The teachers are expected to devote to the research and development of courses. Self-reflection and self-development are the necessary ways for teachers to promote themselves in order to adapt to the quickly changing society.

\section{Opportunities AND Challenges FACED By the COLlEGE ENGLiSH TEACHERS}

\section{A. Opportunities Faced by the College English Teachers}

The reform of college English teaching has been conducted for many years and it is charactirized by promoting the informatization of education. College English teaching is thirsty for a new teaching mode which is supported by the computer network technology. The improvement of teaching conditions, especially the increasingly all-pervading modern education technology has provided the material basis for the college English reform. The college English 
teaching reform has seized the opportunities of the revolution of the information technology. A considerable number of publishing companies, such as Foreign Language Teaching and Researching Press, have developed teaching software with diverse functions and follow the rules of language learning. These kinds of teaching software can replace some repeating work of the teachers, such as listening, grammar and simultaneous imitation which need repeated dill.

The college English teaching reform also brings college English teachers opportunities to enhance their own abilities. With the advancement of reform, an increasing number of college English teachers have access to the different types of training concerning with college English reform. They learn and participate in many academic exchanges through various channels. They've also experienced changes in teaching practice of various aspects during the course of the implementation of the new teaching modes. The college English teachers reflect on the gains and losses of the teaching continously and therefore improve their level of teaching and scientific research.

In recent years, the Foreign Language Teaching and Researching Press holds national English teaching and teacher development serial seminars every summer in Bejing or other cities which provides the college English teachers with a platform for pursuing their studies and enhancing their teaching and researching ability. The teachers are encouraged to take an full participation in all kinds of activities, to think actively and share their teaching experience. An open and interactive learning team is also expected to be created with the aim to improve the teachers' theoretical level and innovative capability.

\section{B. Challenges Faced by the College English Teachers}

Since 2002, the Ministry of Education has initiated the college English teaching reform in 180 universities and colleges and it has brought about a series of deep changes and these changes have exerted a profound influence on the learning and teaching habits of the college English students and teachers and urged them to reflect on and pay a close attention to all the factors relevant with the college English teaching.

The students nowdays are quite different from before. They were born in the 1990s and they grew up with the widely used computers and Internet. With computers linked to the internet, they have more access to the rich and timely information from the Internet. They have more distinctive personality and are not satisfactied with the teachers' teaching item by item from the textbooks. To meet the demands of the students for the English learning, the teachers have to improve their own capacity.

TRADITIONAL TEACHING MODE VS AUTONOMOUS LEARNING MODE

\begin{tabular}{|c|c|c|}
\hline & Traditional teaching mode & Autonomous learning mode \\
\hline Teaching object & Teach the language knowledge & Cultivate integrated capacity of English learning \\
\hline Teaching preparation & $\begin{array}{l}\text { The teachers analyze the teaching material and } \\
\text { draw up teaching plan }\end{array}$ & $\begin{array}{l}\text { The teachers analyze teaching resources and the } \\
\text { learners and make coursewares and online } \\
\text { courses }\end{array}$ \\
\hline Teaching contents & Teaching material & $\begin{array}{l}\text { Teaching material, coursewares and onling } \\
\text { courses }\end{array}$ \\
\hline Teaching methods & $\begin{array}{l}\text { The teachers dominate the class and the students } \\
\text { receive the information passively }\end{array}$ & $\begin{array}{l}\text { The learners are the core of the class and they } \\
\text { attend the class activities actively }\end{array}$ \\
\hline Teaching resources & Teaching materials and other printed materials & $\begin{array}{l}\text { Printed materials, visual coursewares, } \\
\text { mutil-media online courses and internet } \\
\text { resources }\end{array}$ \\
\hline Teaching environment & Classroom (blackboard, chalks and recorders) & $\begin{array}{l}\text { Multi-media classroom, autonomous learning } \\
\text { centre, internet and the second class }\end{array}$ \\
\hline Teaching procedures & The same procedures & $\begin{array}{l}\text { Specific procedures according to the different } \\
\text { levels of the learners }\end{array}$ \\
\hline Teaching evaluation & $\begin{array}{l}\text { The teachers make evaluations on the learners (the } \\
\text { scores of the tests, classroom performance, } \\
\text { attendance rate) }\end{array}$ & $\begin{array}{l}\text { The evaluation of the teachers, the } \\
\text { self-evaluation of the learners, the evaluations } \\
\text { among the learners, the evaluations of the } \\
\text { learning process (written examination, oral } \\
\text { examination, classroom performance and the } \\
\text { records of the online learning ) }\end{array}$ \\
\hline The role of teachers & Hands-on providers of the knowledge & $\begin{array}{l}\text { The guide, organizer and the managers of the } \\
\text { class }\end{array}$ \\
\hline
\end{tabular}

From the chart above, what conclusion can be easily drawn is that the traditional teaching mode cannot suit the development of the society any more, autonomous learning mode should be adopted by the college English teacher. Weden, A. (1991) pointed out that the autonomy learning is the bisic capacity for the human race to survive and develop.

Besides, the college English teachers have to bear multiple pressures such as the title of a technical post and the record of formal schooling. In the 1990, the universities in China expanded the enrollment of the students and they have a sharp increase of the need for the English teachers. In the initial stage of the expanded enrollment, English teachers are mainly undergraduates. The postgraduates became popular after 2000 and an increasing number of teachers work hard to achieve a Doctor's degree.

An increasing number of universities and colleges are implementing reforms of college English teaching. Some universities set up compulsory English courses related with the majors of their departments. The periods of college English teaching are correspondingly cut. Take Shan dong Jiao tong University as an example. It has set up courses 
such as Automobile English, Mechanical English, Maritime English and so on. The periods of English course has been cut from the original 75 periods to 45 periods for each term. It is inevitable that a lot of English teachers will be at the risk of losing chances to teach. Accordingly, a large number of college English teacher are confronted with new challenges brought by the curriculum reform and they are forced to change their traditional concepts about college English teaching.

Meanwhile, under the current evaluation system of the nation, the promotion of the professional status of the college teachers depends mainly on the articles published and scientific research projects conducted. The chances of the promotion of the professional status would be slim if the number of the articles published and the scientific research projects conducted is enough or the level of them is low. On one hand, the college English teachers bear high pressures from the work. On the other hand, a majority of them have to complete heavy teaching tasks and the average periods a week are 12 to 16 which greatly shortened the time doing scientific research.

\section{Ways to Improve the Development of the COLLEGE ENGLish TEACHERS}

In order to break through the dilemma mentioned above, the college English teachers should have a clear understanding of the current situation and their own conditions and therefore have a clear self-evaluation in order to improve their comprehensive and professional quality. Only in this way can the collge English teachers promote their career with the professional sustainble development.

\section{A. Reevaluation of the Activities of College English Teaching}

Gohenn, D. A. (1998) pointed that second language teaching in recent years has moved away from the ruest for the perfect teaching method, focusing instead on how successful teachers and learners acturally achieve their goals. College English teaching is not as monotonous and dull as before. The teachers are no longer the echo of the text books. Teaching activities are filled with communication information technologies and the work of the teachers should be more creative. Teaching is a kind of complicated experience full of passion.

First of all, the cellege English teachers should have a thorough, comprehensive and brand-new understaning of the students who are the teaching objects. Students' personalities should be encouraged instead of being confined. The classroom of foreign language teaching is expected to be created as a place where language and ideas are exchanged vividly. Axelord, J. (1973) stated that the activities of both the teachers' teaching and the students' learning are a process filled with imagination and creation as well. Secondly, the college education shouldn't be confined to the pass of knoeledge and the training of skills any longer. The teaching activity must be a comprehensive process which aims at cultivating students' sentiment, enriching their knowledge, building up their willpower and improving their behavior. Also, Brown, H. D.(2001) pointed out that teaching is guiding and facilitating learning, enabling the learner to learn, setting the conditions for learning. The teachers' understanding of how learner learns will determine the philosophy of education. Hall, J. K. (2005).stated that in the classrooms, teachers and students together create communities based on shared goals, shared resources and shared patterns and norms for participating as legitimate members of the communities. Therefore, the teachers should attach importance to the mutual communication with the students and develop a favorable interaction circulation mechanism of teaching and learning.

\section{B. To Be Compound Teachers of ESP and EAP through Cooperative Teaching and School-based Training}

In order to meet the demands of the society and current college English teaching, the teachers should develop themselves with the aim to become compound teachers of ESP (English for Special Purposes) and EAP (English for Academic Purposes). In order to meet the course requirements, the cellege English teachers should develop their application abilities such as to be able to read and discuss articles in the international meetings and professional communications, to be able to translate articles introducing cultures and local customs of China, to be able to translate the document literatures and newspapers with the help of dictionaries and so on.

It is advisable for the teachers to pursue their interdisciplinary studies who have the background of academic and professionable learning experience or interest. The teachers can improve themselves with the help of the internal resources of their own universities through attending related classes or cooperative teaching. They can also obtain qualification of ESP teaching after passing the exams of the ESP courses. Also, the college English teachers should pay special attention to the updated trends of their academy and apply the vivid examples and cases to the teaching activities.

The interdisciplinary cooperation of the teachers who teach language and other professions is a preferabe way to enhance the college English teachers' teaching ability and level. Teachers who teach language and other professions can learn from other's strong points and to make uo their own deficiencies. The support of the university and college is necessary to make it true. For example, the universities and colleges can form effective training mechanism. The ESP teachers can construct and enrich their knowledge system and therefore expand and enhance their academic knowledge and teaching ability to complete transformation from single type to compound teachers.

\section{Teaching and Researching Cooperation Team Is a Creative Way to Explore College English Teaching}

The professional development of college English teachers is also the process of "team learning" under the "shared 
vision". "Shared vision" refers to the common values and missions exist in teachers' minds. It is the kind of power which can inspire teachers to work together to complete a vision or goal. Only individual learning under "shared vision" can be viewed as team learning, which is characterized by collaborative peer learning. (Jia Aiwu, 2003)

Oxford, R. (1990) stated that the college English teachers should have a clear mind and understanding of their knowledge structure and the characteristics and advantages of their academy. They shouldn't work and teach as an individual as before any longer. Team cooperation is a new trend in the current college English teaching. The teachers are expected to be given opportunities to expand their knowledge and pursue their studies in the area of interdiscipline. Teaching and researching cooperation teams, such as the Britain and American cooperation team, commerical English cooperation team, Aacademic writing cooperation teams and so on, are encouraged to be set up. Each cooperation team is led by a associate professor or professor and conduct studies and researches in such aspects as the set of curriculum, the analysis of curriculum need etc.

In the process of the teaching practice, the college English study and reseach the academy characteristics in depth and the specific teaching ways and methods. The teachers are aiming at becoming professors in their specific area through looking for appropriate knowledge width and depth and forming their own hierarchy.

\section{CONCLUSION}

The college English teaching and researching reform has been undergoing for many years and is imperative under the current circumstances. The reform has brought both challenges and opportunities to the college English teachers. Confronted with the fast development of the institutions of the higher educations and adjustments adopted by the universities, the college English teachers are expected to adapt themselves to the new trends of teaching and researching through effective ways mentioned above.

First of all, the college English teachers should be fully aware that it is significant for them to make self-development professionally. Secondly, the schools should try their best to provide college English teachers abundant resources and favorable conditions to ensure the development of the teachers. To meet the demands of teachers' development, the school is supposed to hold academic activities as more as possible, providing a platform for mutual learning and communication among teacher. Besides, some kinds of incentives are necessary to support the development of the college English teachers. For example, it is advisable for the schools to provide the teachers with a certain amount of bonus and welfare fund, and with more opportunities to obtain training. Only by doing these can the college English teachers' potential be exploited to the largest extent and the teachers have a good good development and bright future.

\section{REFERENCES}

[1] Axelord, J. (1973). The University Teacher as Artist. San Francision: Jossey-Bass.

[2] Brown, H. D. (2001). Principles of Language Learning and Teaching (3nd edn). NY: Longman.

[3] Cai Jigang (2007). Sduties on the teaching characteristics and policies of the college English teaching under the reform. Beijing: Foreign Language Teaching and Researching.

[4] Gohen, D. A. (1998). Strategies in Learning and Using a Second Language. Harlow: Longman

[5] Hall, J. K. (2005). Teaching and Researching Language and Culture. Beijing: Foreign Language Teaching And Research Press.

[6] Jia Aiwu. (2005). An empirical Study on college teachers' development. Shanghai: East China Normal University.

[7] Oxford, R. (1990). Language Learning Strategies: What Every Teacher Should Know. Boston: Heinle\& Heinle.

[8] Rui Yanping. (2011). An Empirical Study on College English Teacher' Professioal Development. Beijing: National Defence Industry Press.

[9] Villegas-Reimers, E. (2003). Teacher professional development: An international review of the literature. Delacroix: France: International Institute for Educational Planning.

[10] Weden, A. (1991). Learner Strategies for Learner Autonomy: Planning and Implementing Learner Training for Language Learner. London: Prentice Hall International.

[11] Yu Mingli. (2005). Bilingual teaching and college English teaching reform. Wu Han: The Higher Education Research.

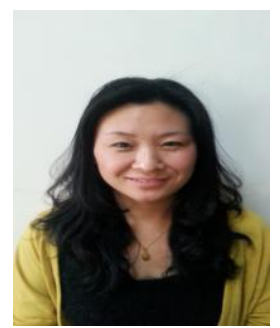

Qian Li was born in Baoding, Hebei province. The author graduated from Chongqing University in Chongqing, China in 2001 and gained the Bachelor's degree of Arts, majoring in English. In 2008, the author gained the Master's degree of Arts in Shandong Normal University.

She has been an English teacher from July of 2001 till now in Shandong Jiaotong University. In October of 2006, she gain the qualification of being an lecturer. During these years from 2001 to 2013 she has taken the foreign language teaching seminars organized by the foreign language teaching and research press for six times in the summer holidays. She has published 21 articles concerning foreign language teaching and researching in recents years. Some of the articles published are as the following: Oversears English, (Hefei, China, Anhui Science \& Technology Publishing House, 2010); Journal of Changchun University of Science and Technology, (Changchun, China, Editorial Board of Journal of Changchun University of Science and Technology, 2011); Time Education (Chengdu, China, Publishing Press of Time Education, 2010). Cross-cultural communication, teaching methods and the study of English as a foreign language are the current research interests of the author.

Ms. Li was the associate editor of Foreign Language Research and Practice which is published by Jilin University publishing press and was awarded "The Best Ten English Teachers of Shandong Province" in 2006. 